\title{
Pathogenicity Evaluation of Eight Egyptian Isolates of Entomopathogenic Nematodes against Two Tick Species; Argas persicus and Boophilus annulatus EL Roby, A. S. M. H. ${ }^{1}$; M. Z. A. Rezk ${ }^{2}$ and M. S. M. Shamseldean ${ }^{2}$ ${ }^{1}$ Plant Protection Dept. Faculty of Agriculture, Minia University, Egypt ${ }^{2}$ Department of Zoology and Agricultural Nematology, Faculty of Agric. Cairo University, Egypt. Corresponded author mail to: ahmed.hussien1@mu.edu or elrobyahmed1980@Gmail.com
}

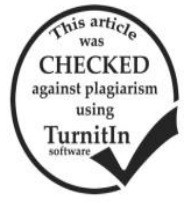

\section{ABSTRACT}

Eight Egyptian isolates of entomopathogenic nematodes (EPN), four belong to the genus Heterorhabditis and four belong to Steinernema were evaluated against adult females of the soft tick Argas persicus and engorged females of the hard tick, Boophilus annulatus in the laboratory. Results indicated that two EPN isolates (A4 and 10k) of Heterorhabditis were rapidly fatal and have high pathogenicity ( $100 \%$ mortality after 72 hours) against $A$. persicus when treated with 1000 nematode Infective Juveniles (IJs/ml). Meanwhile, only one isolate (5B) of Steinernema gave accumulated mortality of $93.33 \%$ against $A$. persicus. Furthermore, Heterorhabditis isolates (10 K and A4) caused $93.33 \%$ and $86 \%$ mortality to B. annulatus. The most effective EPN isolates of Steinernema were 5B and AT4 against B. annulatus, they both gave ca $86.7 \%$ mortality. The $\mathrm{LC}_{50}$ values of Heterorhabditis spp. (A4 and 10K isolates) after $72 \mathrm{hrs}$ post infection and $\mathrm{LT}_{50}$ were $(27.03$ and $257.03 \mathrm{IJs} / \mathrm{ml})$ and (11.94 and $19.2 \mathrm{hrs}$.), respectively against $A$. persicus. While, the $\mathrm{LC}_{90}$ was 360.24 and $765.72 \mathrm{IJs} / \mathrm{ml}$ for A4 and $10 \mathrm{~K}$ isolates, respectively. Meanwhile, A4 and $10 \mathrm{~K}$ isolates exhibited relatively high values of $\mathrm{LC}_{50}, \mathrm{LC}_{90}$ and $\mathrm{LT}_{50}$ against $B$. annulatus, represented by $(358.57 \pm 0.71$ and $812.83 \mathrm{IJs} / \mathrm{ml})$; $(1258.9$ and $2485.9 \mathrm{IJs} / \mathrm{ml}$.) and $(25.64$ and $51.28 \mathrm{hrs}$.$) , respectively. The present study$ cleared that Entomopathogenic nematodes (EPN) isolates of the genus Heterorhabditis spp. (A4 and 10K) are potentially useful biological tools for tick control.

Keywords: Biological control, Argas persicus, Boophilus annulatus, Entomopathogenic nematode, Heterorhabditis spp., Steinernema spp.

\section{INTRODUCTION}

Soft and hard ticks are very serious obligate hematophagous ectoparasites of birds and mammals in all worldwide subtropical countries. Tick problems and diseases transmitted by ticks are one of the main difficulties in these countries for the development of livestock breeding (Guglielmone et al. 2003). They cause direct damage to their animal hosts, since they are vectors of many varieties of human and animal pathogens. consider the most important vectors of pathogens (viruses, bacteria, and protozoa) affecting human and cattle worldwide (Peter, 2005; Jongejan and Uilenberg 2005 and De la Fuente et al. 2008). Tick control is difficult for a number of reasons; ticks lay huge number of eggs, have more than one developmental stage and parasitize numerous hosts. Chemical control with acaricides considered the best method but development of resistant ticks to these acaricides (Foil et al. 2004) remains a big problem. Furthermore, adverse effects of chemical acaricides (acute and chronic toxicity) on the hosts, contamination of animal and plant products, such as milk and meat (George et al. 2008) have worsen the problem. So, the development of alternative safe methods for tick controls becomes necessary. Among biocontrol agents tested against soft ticks were entomopathogenic nematodes (EL-Sedawy and Habib 1998, EL-Sadawy and Abdel-Shafy 2007, Basu et al., 2012) and fungi (Samish et al. 2004, Ostfeld et al. 2006, Samish et al. 2008).

Entomopathogenic nematodes exhibited high efficiency against Ixodidae and Argasidae (Kaaya et al. 2000, Hussaini 2001) and showed highly virulent towards mature and immature stages of soft tick, Argas persicus in the laboratory (EL-Sedawy and Habib 1998) The efficiency of EPN against the Egyptian cattle tick $B$. annulatus in the laboratory and the field is poorly studied. Thus, this work was conducted to shed light on the susceptibility of two tick species to eight indigenous nematode isolates in the laboratory and to determine the potent nematode isolates as well as the most effective concentration required to apply in the field.

\section{MATERIALS AND METHODS}

The experiments were carried out at the laboratory of the Applied Center for Entomonematodes (ACE), Department of Agricultural Zoology and Nematology, Faculty of Agriculture, Cairo University and repeated in Plant Protection Dept., Faculty of Agriculture, Minia University at the same laboratory environment.

\section{Animal sources:}

Ticks;

The ticks, Boophilus annulatus adults were collected as engorged females from the ground below the cows' in their cattle farms in Giza Governorate. The collected ticks were incubated at $25{ }^{\circ} \mathrm{C}$ and $75 \% \mathrm{RH}$ for laboratory experiments. Semi and fully engorged adult of Argas persicus were collected from the chicken breeding houses at Shosha region, Minia governorate. Ticks were identified according to (Hoogstraal et al. 1981).

Nematode propagation:

The eight nematode isolates used in this work were propagated and reared on last instar larvae of Gallaria mellonella L. (Lepidoptera: Pyralidade) (Ehlers 2001; EL Roby 2011 and 2018). Last instar larvae of $G$. mellonella were reared on old bee wax at $28 \pm 2{ }^{\circ} \mathrm{C}$ and relative humidity $65 \pm 5 \%$ in the insect rearing laboratory. The emerging infective juveniles (IJs) were harvested from nematode traps and stored in sterilized water at $10^{\circ} \mathrm{C}$ (Yadav and Lalramliana 2012). All emerged nematode infective juveniles (IJs) were stored at $8^{\circ} \mathrm{C}$ and used within a range of two weeks of nematode harvest. 
1. Evaluation the virulence of EPN isolates against tested ticks:

To evaluate the virulence of all tested nematode isolates against engorged females of $B$. annulatus and adults of $A$. persicus, ten females placed in each of $5 \mathrm{~cm}$ diameter Petri dishes with filter paper and infected with 1000 IJs of nematodes isolated in $1 \mathrm{ml}$. of distilled water (Samish and Glazer 1992) under laboratory conditions. Each treatment was replicated three times (three Petri dishes/ treatment). The experiment was repeated twice. All the treatments were incubated at $25^{\circ} \mathrm{C}$ and $75 \% \mathrm{RH}$. Petri dishes were checked after 24, 48 and $72 \mathrm{hrs}$ post application and mortality was recorded on each interval. Mortality percentage was corrected using Schneider-Orellis formula (Puntener 1981) at each intervals.

Corrected Mortality \% $=\frac{\text { (Mortality \% in treatment -Mortality \% in control) }}{100-\text { r.montrol mortality }} \mathrm{X} 100$

The virulence of all tested nematode isolates against engorged females of $B$. annulatus and adults of Argas persicus was assessed as corrected mortality \%. Completely randomized design was used. ANOVA test was applied and means of mortality were differentiated with the Least Significant Differences (LSD) test.

\section{Susceptibility of $B$. annulatus and Argas persicus} females to $\mathrm{A} 4$ and $10 \mathrm{~K}$ isolates.

Based on the corrected mortality \% obtained in the first experiment, the lethal concentration values $\left(\mathrm{LC}_{50}, \mathrm{LC}_{90}\right.$ and $\left.\mathrm{LC}_{99}\right)$ of the most virulent strains (A4 and $10 \mathrm{~K})$ as well as the time required to kill $50 \%$ of the tick population $\left(\mathrm{LT}_{50}\right)$ were determined.

Estimation the lethal concentration values (LC50, LC90 and LC99):

Suspension of infective juveniles from two nematode isolates of Heterorhabditis spp. (A4 and $10 \mathrm{~K})$, were poured into three 5-cm diameter Petri dishes with filter paper. The suspension contained various concentrations of infective juveniles i.e. 100, 200, 300, 400,500 , and 1000 IJs per replicate on soft ticks and $250,500,750,1000,1500$ and 2000 IJs per replicate on hard ticks and the control treatment was done with distilled water without nematodes. Ten fully engorged females of $B$. annulatus or $A$. persicus were placed in each Petri dish (replicate). Each treatment was replicated three times (three Petri dishes/ treatment). All the treatments were incubated at $25{ }^{\circ} \mathrm{C}$ and $75 \% \mathrm{RH}$. The mortality percentage was determined daily for three successive days. The experiment was repeated two times. Corrected mortality means were subjected to the Probit analysis to calculate the lethal concentrations (Finney 1971) after 72 hrs.

Estimation the $\mathbf{L T}_{\mathbf{5 0}}$ value:

To evaluate the time required to kill $50 \%$ of the tick population $\left(\mathrm{LT}_{50}\right)$ due to the impact of the selected nematode isolates as the most potent nematodes. The same technique was adopted. Results were taken after 2 , $6,12,16,24,36$ and 72 hours with a volume of $1.0 \mathrm{~mL}$. of aqueous suspension per Petri dish with a concentration of $\mathrm{LC}_{99}$ for each strain. Three replicates were used for each treatment. The experiment was replicated twice. Corrected mortality means and log time were subjected to the Probit analysis to calculate $\left(\mathrm{LT}_{50}\right)$ (Finney 1971).

\section{RESULTS AND DISCUSSION}

Eight isolates of local entomopathogenic nematodes belong to the genera Heterorhabditis and Steinernema were tested against the females of the soft tick, A. persicus and the hard tick, B. annulatus four of these EPN isolates belong to Heterorhabditis spp. (A4, SNAB, 10K and S4) and the other four belong to Steinernema spp. (5B, AT4, B32 and 5S). All these isolates were ranked according to their virulence which measured by their accumulated mortality percentages within three days following nematode infections (Tables 1 and 2). Data in Table 1 showed that, the most potent isolates belong to the genus Heterorhabditis were A4 and $10 \mathrm{~K}$. They highly affected the soft tick, A. persicus, and caused $100 \%$ mortality after 72 hours post nematode treatments, followed by $\mathrm{S} 4$ which gave accumulated mortality of $93.33 \%$ after 72 hrs with no significant differences between them. In addition, isolates A4 and $10 \mathrm{~K}$ showed rapid pathogenicity against A. persicus ( 86.7 and 83.3 respectively) after 24 hours of infection. While the lowest virulent isolate of Heterorhabditis spp. was, S4 since it caused $26.7 \%$ and $43.77 \%$ mortality after $24 \mathrm{hrs}$ and $48 \mathrm{hrs}$ post treatment (Table1). Two strains belong to genus Steinernema (5B and 5S) both recorded $93.33 \%$ mortality after $72 \mathrm{hrs}$ post treatment of $A$. persicus.

Table 1. Virulence of entomopathogenic nematode isolates at $1000 \mathrm{IJs} / \mathrm{ml}$ against the soft tick A. persicus throughout 3 days post nematode infections.

\begin{tabular}{|c|c|c|c|c|}
\hline \multirow{2}{*}{$\begin{array}{l}\text { Nematode } \\
\text { genera }\end{array}$} & \multirow[t]{2}{*}{ Strain } & \multicolumn{3}{|c|}{$\begin{array}{c}\text { Mortality\% post treatment } \\
\text { intervals (hrs.) }\end{array}$} \\
\hline & & 24 & 48 & 72 \\
\hline \multirow{4}{*}{ Heterorhabditis } & A4 & $86.7 \pm 11.5$ & $93.3 \pm 11.5$ & $100.0 \pm 0.0$ \\
\hline & SNAB & $53.3 \pm 11.5$ & $80.0 \pm 10.0$ & $93.3 \pm 11.5$ \\
\hline & $10 \mathrm{~K}$ & $83.3 \pm 15.3$ & $93.3 \pm 11.5$ & $\underset{5}{100.0 \pm 11}$ \\
\hline & $\mathrm{S} 4$ & $26.7 \pm 11.5$ & $43.7 \pm 05.8$ & $93.33 \pm 5.7$ \\
\hline \multirow{4}{*}{ Steinernema } & $5 B$ & $40.0 \pm 10.0$ & $80.7 \pm 11.5$ & $\begin{array}{c}93.33 \pm 11 . \\
5\end{array}$ \\
\hline & AT4 & $30.0 \pm 10.0$ & $66.7 \pm 11.5$ & $80.0 \pm 0.0$ \\
\hline & B32 & $26.7 \pm 11.5$ & $46.66 \pm 8.5$ & $60.0 \pm 0.0$ \\
\hline & $5 \mathrm{~S}$ & $40.0 \pm 00.0$ & $86.7 \pm 11.5$ & $93.3 \pm 11.5$ \\
\hline $\operatorname{LSD}(.01)^{* * *}$ & & 16.27 & 23.51 & 21.54 \\
\hline
\end{tabular}
LSD test.

As shown in Table (2), the most potent isolates tested belong to Heterorhabditis spp. against $B$. annulatus were $10 \mathrm{~K}$ and A4 isolates, they showed accumulated mortality of 93.33 and $86 \%$ after 72 hours post nematode exposure, respectively. While the most effective isolates from Steinernema against $B$. annulatus were (5B and AT4), both gave accumulated mortality of $(86.7 \%$ \%). Moreover, the least virulent species from Heterorhabditis was S4 it gave mortality of 10, 33.3 and $76.7 \%$ after 24, 48 and $72 \mathrm{hrs,}$, respectively. The lowest mortality rate was recorded with isolate $(5 \mathrm{~S})$ against $B$. annulatus which gave $3.33,6.7$ and $23.33 \%$ mortality after 24,48 and $72 \mathrm{hrs}$ following the exposure to 
nematodes. In contrast, the best isolates of Steinernema tested against the hard tick Boophilus annulatus were (5B and AT4). They gave $86.7 \%$ accumulated mortality after $72 \mathrm{hrs}$ post nematode infection. Highly significant differences were recorded between all nematodes isolates used to kill ticks and the control at all times of exposure. Data in Table 1 and 2 demonstrate that, the mortality percentages caused by Heterorhabditis isolates increased with exposure time to reach 100,100 , 93.33 and $93.33 \%$ after $72 \mathrm{hrs}$ of exposure to A4, 10K, SNAB and S4 nematode isolates, respectively. While mortality rate using nematode isolates of Steinernema spp. never reached $100 \%$ through the three days of nematode exposure to the ticks.

The $\mathrm{LC}_{50}$ and $\mathrm{LC}_{90}$ values of the tested isolates A4 and $10 \mathrm{~K}$ against $A$. persicus and hard tick, $B$. annulatus females are given in Table (3) together with their Slope (b) of LDP Line.

In respect to $\mathrm{LC}_{50}$ and $\mathrm{LC}_{90}$ values: The obtained data revealed that $\mathrm{A} 4$ isolate had the highest virulence on both $A$. persicus and $B$. annulatus females, presenting $\mathrm{LC}_{50}$ equal to 27.03 (18.69- 39.04) and $\mathrm{LC}_{90}$ equal to $103.18 \mathrm{IJs} / \mathrm{ml}$. (for $A$. persicus), while, it was significantly less virulent against $B$. annulatus with $\mathrm{LC}_{50}$ value of 360.24 ( $\left.311-413.2\right) \mathrm{IJ} / \mathrm{ml}$. and $\mathrm{LC}_{90}$ equal to $1258.9 \mathrm{IJ} / \mathrm{ml}$. On contrary, $10 \mathrm{~K}$ isolate was significantly less virulent against the soft and hard ticks ( $\mathrm{LC}_{50}$ was 257.03 (213.7-322.8) and $\mathrm{LC}_{90}$ of 765.72 (for A. persicus) and $\mathrm{LC}_{50} 812.83 \mathrm{IJs} / \mathrm{ml}$ (657.8-1079.2) (for B. annulatus). Also, $10 \mathrm{~K}$ isolate was the least virulent, with $\mathrm{LC}_{50}$ value of $812.83(657.8-1079.2) \quad \mathrm{IJ} / \mathrm{dish}$ against $B$. annulatus females. Based on these results, the (A4) isolate of Heterorhabditis sp. considers a promising candidate as a biological control agent against both soft and hard ticks.

The third assay confirmed the quick pathogenicity of the isolates (A4 and $10 \mathrm{~K}$ ). $\mathrm{LT}_{50}$ and $\mathrm{LT}_{90}$ values of $\mathrm{A} 4$ and $10 \mathrm{~K}$ isolates against $A$. persicus and $B$. annulatus were estimated and presented in Table (4). The obtained data cleared that the two tested isolates are promising ones for controlling both soft and hard ticks, especially A4 isolate. It was the fastest and potent one against ticks, which gave rapid pathogenicity of $\mathrm{LT}_{50}\left(11.94 \mathrm{hrs}\right.$.) and $\mathrm{LT}_{90}(54.59 \mathrm{hrs}$.) in case of $A$. persicus and 25.64 and $104.48 \mathrm{hrs}$. in case of $B$. annulatus. These values were 19.2 and 104.48 and 51.28 and $626.05 \mathrm{hrs}$. for the other $(10 \mathrm{~K})$ isolate in the case of $A$. persicus and B. annulatus, respectively.

Table 2. Virulence of Entomopathogenic nematode isolates at $1000 \mathrm{IJs} / \mathrm{ml}$ against the hard tick B. annulatus throughout 3 days post nematode infections

\begin{tabular}{|c|c|c|c|c|}
\hline \multirow{2}{*}{$\begin{array}{l}\text { Nematode } \\
\text { genera }\end{array}$} & \multirow{2}{*}{ Strain } & \multicolumn{3}{|c|}{$\begin{array}{c}\text { Mortality\% post treatment } \\
\text { intervals (hrs.) }\end{array}$} \\
\hline & & 24 & 48 & 72 \\
\hline \multirow{4}{*}{ Heterorhabditis } & A4 & $80.0 \pm 10.0$ & $80.0 \pm 10$ & $86.7 \pm 5.8$ \\
\hline & SNAB & $40.0 \pm 10.0$ & $40.0 \pm 17.3$ & $83.3 \pm 11.5$ \\
\hline & $10 \mathrm{~K}$ & $33.3 \pm 17.3$ & $66.7 \pm 11.5$ & $93.33 \pm 5.8$ \\
\hline & $\mathrm{S} 4$ & $10.0 \pm 00.0$ & $33.3 \pm 5.8$ & $86.7 \pm 20.5$ \\
\hline \multirow{4}{*}{ Steinernema } & $5 \mathrm{~B}$ & $30.9 \pm 17.0$ & $53.3 \pm 10.0$ & $86.7 \pm 11.5$ \\
\hline & AT4 & $36.7 \pm 11.5$ & $60.0 \pm 05.8$ & $86.7 \pm 20.5$ \\
\hline & B32 & $13.3 \pm 5.9$ & $60.0 \pm 11.5$ & $80.0 \pm 10.0$ \\
\hline & $5 \mathrm{~S}$ & $3.33 \pm 5.8$ & $06.7 \pm 05.7$ & $23.33 \pm 5.7$ \\
\hline $\operatorname{LSD}(.01)^{* * *}$ & & 16.17 & 29.68 & 22.54 \\
\hline
\end{tabular}

Table 3. LC50 and LC90 of Heterorhabditis isolates (A4 and 10K), when treated with LC99 against the nonfed and engorged females of the soft tick, Argas persicus and the hard tick, Boophilus annulatus. \begin{tabular}{lllll}
\hline Tested tick species Nematode isolates & Slope (b) of LDP Line & LC50 (IJs/female) & LC90 (IJs/female)
\end{tabular}

\begin{tabular}{lcccc}
\hline Argas persicus & $\mathrm{A} 4$ & 2.12 & $\begin{array}{c}27.03 \\
(18.69-39.04)\end{array}$ & 103.18 \\
& $10 \mathrm{~K}$ & 2.7 & $(213.7-322.8)$ & 765.72 \\
\hline \multirow{3}{*}{ Boophilus annulatus } & $\mathrm{A} 4$ & 2.12 & $\begin{array}{c}360.24 \\
(311.1-413.2)\end{array}$ & 1258.9 \\
& $10 \mathrm{~K}$ & 2.68 & $(657.8-1079.2)$ & 2485.9 \\
\hline
\end{tabular}

Table 4. $\mathbf{L T}_{50}$ and $\mathbf{L T}_{90}$ of Heterorhabditis isolates (A4 and 10K), when treated with LC99 against the non-fed and engorged females of the soft tick, Argas persicus and the hard tick, Boophilus annulatus.

\begin{tabular}{|c|c|c|c|c|}
\hline $\begin{array}{l}\text { Tested tick } \\
\text { species }\end{array}$ & $\begin{array}{c}\text { Nematode } \\
\text { isolates }\end{array}$ & $\begin{array}{l}\text { Slope (b) of } \\
\text { LDP Line }\end{array}$ & $\begin{array}{c}\text { LT50 } \\
\text { (hours) } \\
\end{array}$ & $\begin{array}{c}\text { LT90 } \\
\text { (hours) }\end{array}$ \\
\hline \multirow{2}{*}{$\begin{array}{l}\text { Argas } \\
\text { persicus }\end{array}$} & A4 & 1.94 & $\begin{array}{c}11.94 \\
(9.22-15.2)\end{array}$ & 54.59 \\
\hline & $10 \mathrm{~K}$ & 2.12 & $\begin{array}{c}19.2 \\
(16.39-22.9)\end{array}$ & 73.77 \\
\hline \multirow{2}{*}{$\begin{array}{l}\text { Boophilus } \\
\text { annulatus }\end{array}$} & A4 & 2.1 & $\begin{array}{c}25.64 \\
(19.66- \\
39.92)\end{array}$ & 104.48 \\
\hline & $10 \mathrm{~K}$ & 1.18 & $\begin{array}{c}51.28 \\
(44.27- \\
83.72)\end{array}$ & 626.05 \\
\hline
\end{tabular}

Nematodes are Known to enter their host body cavity mainly via natural orifices. In engorged females of B. annulatus, entomopathogenic nematodes were attracted towards the natural apertures of the ticks and/or penetrate between mouthparts. The eight tested nematode isolates for their anti-tick activity have shown varying degrees of virulence. In our laboratory tests, heterorhabditid isolates were generally more virulent to ticks than steinernematids. Similar conclusion was obtained by (Kaya et al. 2000) that nematodes are virulent against engorged females of the tested African tick species and they attracted towards natural openings in the ticks' body or attempted to penetrate between mouthparts. However, the nematodes mode of invasion has not yet been established. In contrast, a study on Boophilus spp., has shown that, no obvious relationship was observed between the size of spiracles, size of 
genital openings or cuticle thickness and relative susceptibility to entomopathogenic nematodes (ELSadawy and Abdel-Shafy 2007) (EL- Sedawy and Habib 1998, Hassanain et al. 1999, Glazer et al. 2001). This differences may be attributed to the ability of heterorhabditid infective juveniles to penetrate through soft cuticle and thin membranes with the help of a the nematode terminal tooth in their head region (Georgis and Gaugler 1991). The differences in the ability of nematode strains to kill ticks in Petri dishes may be attributed to several factors, including the host finding capability of the nematodes where $B$. annulatus females release volatile attracting compounds and also secrete a water soluble nematode repellent. Ticks are also known to secrete allomones, including squalene, that repel predators (Yoder et al. 1993, Samish et al. 2008). The fact that nematode Infective Juveniles (IJs) may at time survive for up to 4-6 days within the tick can possibly be explained by variability in the efficiency of some anti-nematode factor(s) among individual ticks. It could also be attributed to variation in susceptibility of individual nematodes within the population or to the protection of some nematodes against lethal factors by their invasion into more protective organs inside the tick. (Poinar 1989; and Samish et al. 2004) indicated that $S$. carpocasae and $H$. bacteriophora are infective against aerial and ground spiders (Arachnida). Whereas thousands of Steinernematidis and Heterorhabditidis infective juveniles were needed to kill these spiders, the data show that as few as 100 infective juveniles per female in petri dish produce $100 \%$ mortality of soft ticks and ca $85 \%$ of hard ticks. The results demonstrate that A. persicus and B. annulatus females are highly susceptible to infection by heterorahbditid isolates of (A4 and 10K) and less susceptible to steinernematid isolates (5B and $5 \mathrm{~S}$ ) compared with other non-insect hosts from the same class. Our current data are similar to the results obtained with some nematode susceptible insects (Gaugler 2017)

Although ticks are highly susceptible to nematode infection, they do not seem to be satisfactory hosts for the reproduction of those tested entomopathogenic nematodes. The reproduction and infective juvenile formation in non-insect hosts are rarely completed even when the host has been killed (Poinar 1989). Furthermore, nematode development was inhibited by a host defense reaction of arthropods with low susceptibility such as millipedes (Samish and Glazer 1992). As observed a few days after juvenile nematodes penetrate or injected into ticks, all or most of them die inside their tick host. Although in rare cases they have survived as IJs or even started to develop within the tick but they never completed their life cycle (Benjamin et al. 2002).

Testing tick-nematode interactions, EPN penetrate engorged females of $B$. annulatus tick almost solely via the anus or genital pore (unpublished observations). We also observed that heterorhabditid nematodes killed engorged $A$. persicus and $B$. annulatus females in Petri dishes after less than $12 \mathrm{hrs}$ of exposure, whereas Steinernematidis nematodes needed more than 12 hrs to penetrate into ticks (Glazer et al. 2001). The injection of a single heterorhabditid nematode into a tick can cause mortality (Glazer et al. 2001). Whereas, the doses of EPN needed to kill 50 or $90 \%$ of ticks are comparable to that used commercially in the control of plant insect pests, but the time required to kill ticks is often relatively long (Table 4). Tick mortality caused by EPN seems to be due to the rapid proliferation of the nematode associated symbiotic bacteria within the ticks body, since the nematodes do not go through their natural cycle inside ticks, and most infective juveniles die shortly after entry (Hassanain et al. 1999; Glazer et al. 2001; Samish et al. 2004; FreitasRibeiro et al. 2005; and Gaugler 2017). In vitro experiments demonstrated that tick hemolymph hinders the growth of EPN (Zhioua et al. 1995), but the reason(s) for nematode mortality within ticks is not yet fully understood. Interestingly, when the cuticle of $I$. scapularis was physically slit before nematode infection, the nematodes $S$. carpocapsae and $S$. glaseri reproduced successfully (Zhioua et al. 1995).

Female ticks were killed up to six times quicker (the $\mathrm{LT}_{50}$ was one day for $R$. bursa) than engorged ticks (6 days for R. bursa) (Samish et al. 2004). This may be connected to the strong anti-bacterial activity of the tick haemolymph (Caroli et al. 1996). The eight nematode isolates tested for anti-tick activity showed varying degrees of virulence, however, Heterorhabditidis nematodes were generally more virulent to ticks than Steinernematidis. This fact was proven in the current results and corroborate in several publications by (Hill 1998, Glazer et al. 2001, Freitas-Ribeiro et al. 2005, ElBorai et al. 2007, George et al. 2008, Morton and Del Pino 2008, El-Borai et al. 2012, Gassmann et al. 2012, Laznik and Trdan 2016, Memari et al. 2016, Gaugler 2017). Nematode isolates virulent to one tick stage of one certain tick species were found, in most cases, to be also highly virulent to other tick species and stages (Kaya et al. 2000, Glazer et al. 2001, Samish et al. 2004). Our data confirmed the potentially of local EPN as useful biological tools for tick control because: engorged ticks are susceptible to some EPN and also reside in locations that are preferred by many EPN isolates; in addition immobile ticks attract mobile nematodes. However, the use of nematodes may be limited to defined ecological niches because their pathogenicity is reduced by low humidity and/or temperature, high concentrations of animal manure or silt, and by differences in the susceptibility among the various tick stages and species. The wide genetic variation found among many nematode isolates, and presumably in nematode isolates yet to be found in the future, means that genetic manipulation of nematodes could increase the range of ecological conditions in which they could be successfully applied against ticks. The development of improved commercial formulations is also important. Finally, in-depth studies are needed to clarify the interactions between nematodes and their tick hosts in the field. 


\section{REFERENCES}

Basu, A. K., Basu, M., \& Adesiyun, A. A. (2012). A review on ticks (Acari: Ixodoidea: Ixodidae, Argasidae), associated pathogens and diseases of Trinidad and Tobago. Acarologia, 52(1), 39-50.

Benjamin, M. A., Zhioua, E., \& Ostfeld, R. S. (2002). Laboratory and field evaluation of the entomopathogenic fungus Metarhizium anisopliae (Deuteromycetes) for controlling questing adult Ixodes scapularis (Acari: Ixodidae). Journal of medical entomology, 39(5), 723-728.

Caroli, L., Glazer, I., \& Gaugler, R. (1996). Entomopathogenic nematode infectivity assay: comparison of penetration rate into different hosts. Biocontrol Science and Technology, 6(2), 227-234.

De la Fuente, J., Estrada-Peña, A., Venzal, J., Kocan, K., \& Sonenshine, D. (2008). Overview: ticks as vectors of pathogens that cause disease in humans and animals. Frontiers in Bioscience, 1(13), 6938-6946.

Ehlers, R. U. (2001). Mass production of entomopathogenic nematodes for plant protection. Appl Microbiol Biotechnol, 56(5-6), 623-633.

EL-Sadawy, H.. \& Habib, S. M. (1998). Testing some entomopathogenic nematodes for the biocontrol of Hyalomma dromedarii Koch (Acarina: Ixodidae). J. Union Arab Biol., Cairo, 10 A (1-11).

El-Borai, F. E., Brentu, C. F., \& Duncan, L. W. (2007). Augmenting Entomopathogenic Nematodes in Soil from a Florida CitrusOrchard: Non-Target Effects of a Trophic Cascade. J Nematol, 39(2), 203-210.

El-Borai, F. E., Stuart, R. J., Campos-Herrera, R., Pathak, E., \& Duncan, L. W. (2012). Entomopathogenic nematodes, root weevil larvae, and dynamic interactions among soil texture, plant growth, herbivory, and predation. $J$ Invertebr Pathol, 109(1), 134-142. doi: 10.1016/j.jip.2011.10.012

EL-Sadawy, H. A., \& Abdel-Shafy, S. (2007). Laboratory and field studies on Entomopathogenic nematodes as biocontrol agent for the cattle tick Boophilus annulatus (Acari: Ixodidae). Acarologia, XLVII(12), 25-31.

EL Roby, A., S.M.H,. (2011). Studies on Entomonematodes in Egypt. (Ph.D ), Minia University, Egypt, Minia University, Egypt.

EL Roby, A. S. M. H. (2018). Efficiency of entomopathogenic nematodes (Rhabditida) against Saccharococcus sacchari (Cockerell) (Homoptera: Pseudococcidae) under laboratory conditions. Pakistan Journal of Nematology, 36(1), 59-63.

Finney, D. J. (1971). Probit analysis: a statistical treatment ofthe sigmoid response carve. . Cambrigge Univ. Press, London.

Foil, L., Coleman, P., Eisler, M., Fragoso-Sanchez, H., Garcia-Vazquez, Z., Guerrero, FD.,, Jonsson, N., Langstaff, IG., Li, AY., Machila, N., Miller, RJ., Morton, J., Pruett, JH., \& \& Torr, S. (2004). Factors that influence the prevalence of acaricide resistance and tick-borne diseases. . Veterinary Parasitology, 125(1-2), 163-181.
Freitas-Ribeiro, G. M., Furlong, J., Vasconcelos, V. O., Dolinski, C., \& Loures-Ribeiro, A. (2005). Analysis of biological parameters of Boophilus microplus Canestrini, 1887 exposed to Entomopathogenic nematodes Steinernema carpocapsae Santa Rosa and All strains (Steinernema: Rhabditida). Brazilian Archives of Biology and Technology, 48(6), 911-919.

Gassmann, A. J., Hannon, E. R., Sisterson, M. S., Stock, S. P., Carriere, Y., \& Tabashnik, B. E. (2012). Effects of entomopathogenic nematodes on evolution of pink bollworm resistance to Bacillus thuringiensis toxin Cry1Ac. J Econ Entomol, 105(3), 994-1005.

Gaugler, R. (2017). Entomopathogenic Nematodes in Biological Control : CRC press.

George, J., Pound, J., \& Davey, R. (2008). Acaricides for controlling ticks on cattle and the problem of acaricides resistance. In: Ticks: biology, disease and control. www.intechopen.com , 152 Parasitology Bowman \& Pat Nuttall (Eds.), pp. 408-423, , ISBN (U. Cambridge Ed.). Cambridge University Press.

Georgis, R., \& Gaugler, R. (1991). Predictability in biological control using entomopathogenic nematodes. Journal of economic entomology, 84(3), 713-720.

Glazer, I., Alekseev, E., \& Samish, M. (2001). Factors affecting the virulence of entomopathogenic nematodes to engorged female Boophilus annulatus ticks. Journal of Parasitology, 87(4), 808-812.

Guglielmone, A. A., Estrada-Pena A., Luciana C.A., Mangold A.J., \& J.E., K. (2003). Hosts and distribution of Amblyomma auricularium (Conil 1878) and Amblyomma pseudoconcolor Aragao,1908 (Acari:Ixodidae)Exp. Appl. . Acarol., 29, 131-139. doi: 10.1023/A:1024251020035

Hassanain, M., Derbala, A., Abdel-Barry, N., El-Sherif, M., \& El-Sadawy, H. (1999). Biological control of ticks (Argasidae) by entomopathogenic nematodes. Egyptian Journal of Biological Pest Control, 7, 4146.

Hill, D. E. (1998). Entomopathogenic nematodes as control agents of developmental stages of the black-legged tick, Ixodes scapularis. J Parasitol, 84(6), 11241127.

Hoogstraal, H., Wassef, H. W., \& Buttiker, W. (1981). Ticks (Acarina) of saudi Arabia- Fam. Argasidae, Ixodidae. Fauna of Soudi Arabia, 3, 25-110.

Hussaini, S. (2001). Scope of entomopathogenic nematodes against crop pests. In: Rabindra RJ, Kennedy JS, Sathiah N, Rajasekaran B, Srinivasan $M R$ (eds) Microbial control of crop pests. $C A B$ International, Wallingford, UK, .

Jongejan, F., \& Uilenberg, G. (2005). The global importance of ticks. . Parasitology, Vol. 129, No.suppl, pp. s3-s14, ISSN, 129, 3-14.

Kaaya, G. P., Samish, M., \& Glazer, I. (2000). .Laboratory evaluation of pathogenicity of entomogenous nematodes to Africa tick species. - Ann. N. Y. Acad.Sci., 916, 303-308. 
Laznik, Z., \& Trdan, S. (2016). Attraction Behaviors of Entomopathogenic Nematodes (Steinernematidae and Heterorhabditidae) to Synthetic Volatiles Emitted by Insect Damaged Potato Tubers. J Chem Ecol, 42(4), 314-322. doi: 10.1007/s10886-0160686-y

Memari, Z., Karimi, J., Kamali, S., Goldansaz, S. H., \& Hosseini, M. (2016). Are Entomopathogenic Nematodes Effective Biological Control Agents Against the Carob Moth, Ectomyelois ceratoniae? $J$ Nematol, 48(4), 261-267.

Morton, A., \& Del Pino, F. G. (2008). Effectiveness of different species of entomopathogenic nematodes for biocontrol of the Mediterranean flatheaded rootborer, Capnodis tenebrionis (Linne) (Coleoptera: Buprestidae) in potted peach tree. $J$ Invertebr Pathol, 97(2), 128-133. doi: 10.1016/j.jip.2007.09.003

Ostfeld, R., Price, A., Hornbostel, V., \& Benjamin, A. (2006). Controlling ticks and tickborne zoonoses with biological and chemical agents. . Bioscience, 5, 383-394.

Peter, R., Van den Bossche, P., Penzhorn, BL. \& Sharp, B. . (2005). Tick, fly, and mosquito control-lessons from the past, solutions for the future. . Veterinary Parasitology, Vol. 132, No. 3, (September 2005), pp. 205-15, ISSN.

Poinar Jr, G. (1989). Non-insect hosts for the entomogenous rhabditoid nematodes Neoaplectana (Steinernematidae) and Heterorhabditis (Heterorhabditidae). Revue de nématologie, 12(4), 423-428.
Puntener, W. (1981). Manual for field trails in plant protection. Agricultural Division, Ciba- Geigy Limited. .

Samish, M., Ginsberg, H., \& Glazer, I. (2004). Biological control of ticks. Parasitology. Parasitology, 129, 389-403.

Samish, M., Ginsberg, H., Glazer, I., \& Anti.ticj. (2008). biological control agents: assessment and future perspectives. In: Ticks: biology, disease and control. Alan S. Bowman \& Pat Nuttall (Eds.), pp. 447-469, Cambridge University Press, ISBN 978$0-521-86761$.

Samish, M., \& Glazer, I. (1992). Infectivity of entomopathogenic nematodes (Steinemematidae and Heterorhabditidae) to female ticks of Boophilus annulatus (Arachnida: Ixodidae). Journal of medical entomology, 29(4), 614-618.

Yadav, A. K., \& Lalramliana. (2012). Evaluation of the efficacy of three indigenous strains of entomopathogenic nematodes from Meghalaya, India against mustard sawfly, Athalia lugens proxima Klug (Hymenoptera: Tenthredinidae). J Parasit Dis, 36(2), 175-180. doi: 10.1007/s12639012-0099-y

Yoder, J. A., Pollack, R. J., \& Spielman, A. (1993). An ant-diversionary secretion of ticks: First demonstration of an acarine allomone. Journal of insect physiology, 39(5), 429-435.

Zhioua, E., Lebrun, R. A., Ginsberg, H. S., \& Aeschlimann, A. (1995). Pathogenicity of Steinernema carpocapsae and S. glaseri (Nematoda: Steinernematidae) to Ixodes scapularis (Acari: Ixodidae). Journal of medical entomology, 32(6), 900-905.

\section{Entomopathogenic التقييم المعلي للقدرة المرضية لثمان عزلات محلية من النيماتودا الممرضة Boophilus annulatus و لنوعين من القراد المصري

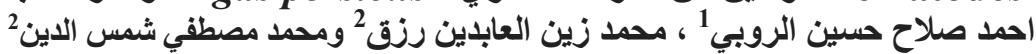

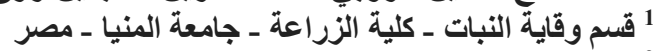

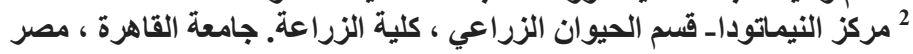

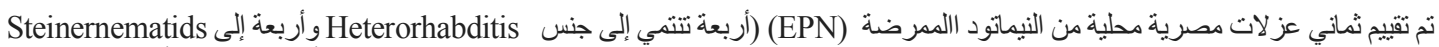

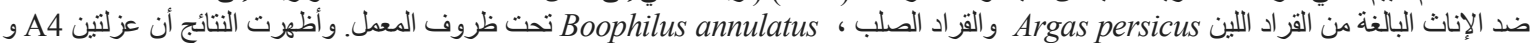

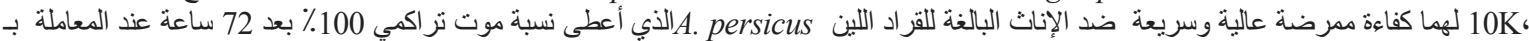

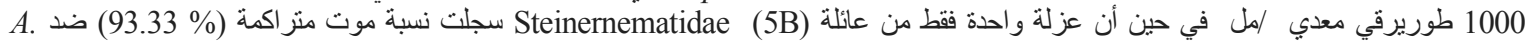

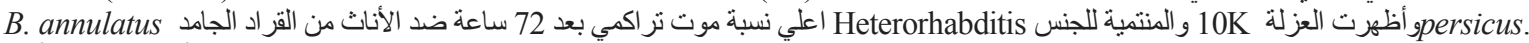

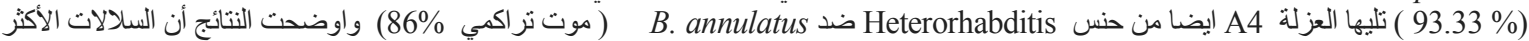

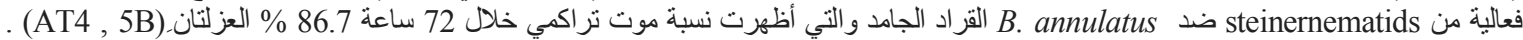

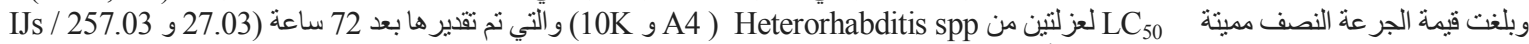

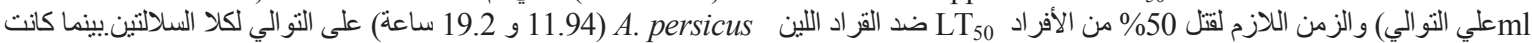

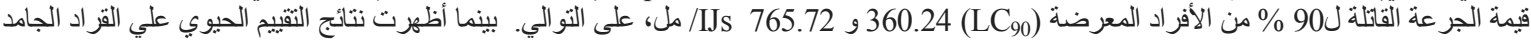
لكلا السلاتين أن قيم

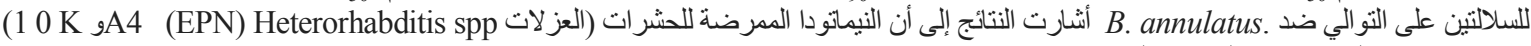

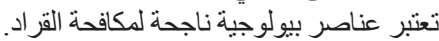

الكلمات المفتاحية: المكافحة البيولوجية ، النيماتودا الممرضة للحشرات ، steinernematids ، Heterorhabditis القر اد اللين Argas persicus و القر اد الجامد Boophilus annulatus 